\title{
The Naturalness and Accuracy of English Short Story Translation into Indonesian
}

\author{
Nur Hasanah Safei \\ nurhasanahsafei92@gmail.com \\ Kisman Salija \\ kismansalija@unm.ac.id
}

\author{
Universitas Negeri Makassar, Indonesia
}

\begin{abstract}
The objectives of this research were to find out the naturalness of English short story translation into Indonesian and to find out the accuracy of English short story translation into Indonesian. This research employed descriptive qualitative research design which conducted at the second year students of MTsN 1 Makassar in academic years 2017/2018 . The researcher used purposive sampling technique by taking one class from the twelve classes. The researcher chooses class VIII-11 which consisted of 40 students. The data were collected using document by translation text and interview. The results showed that the naturalness and accuracy of students' translation of short story entitled The Proud Lion gained score 7-8 with classification "almost completely successful" from 30 students. And 10 students gained score 5-6 with classification "adequate". It was caused by wrong choice of words and they were still less in selecting the indicated meaning so that their translation sound strange, unnatural, inaccuracy for the readers.
\end{abstract}

Keyword: Translation, Naturalness, Accuracy, Short story

\section{INTRODUCTION}

For bilingual people, translation is an activity which indirectly they do every day. Unfortunately, not every bilingual person can become a good translator. Translation is not only changing language from source language (SL) to target language (TL), but also transferring of message from source language to target language. Transferring the message to target language is not an easy thing. Barker (1995) stated that, "translation is difficult, even for people. To begin with, you have to know two languages carefully. And even if you speak two or more languages fluently, it is not a trivial matter to produce a good translation." For that reason, before translator passed the message, the translator has to understand the message accurately, both grammatical and lexical. Therefore, in the process of translating, there are three qualities of translation to follow. There are clarity, accuracy and naturalness. Besides clarity, in translation, the naturalness and accuracy also important thing that must be considered by translator. Newmark (1988:24) stated that the level of naturalness of natural usage is grammatical as well as lexical. It is important that the translation is written in ordinary language, the common grammar, idioms and word that meet that kind of situation. As a result, the target reader can accept the message easily. 
Larson (1998:3)Accuracy in translation consists of studying the lexicon, grammatical structure, communication situation and cultural context of the source language text, analyzing it in order to determine its meaning and then reconstructing this same meaning using the lexicon and grammatical structure which are appropriate in the receptor language and its cultural context.

In addition, Shavit (1986) mention that, in viewing translation as a part of a transfer process, it must be stressed that the subject of stake is not just translation of text from one language to another language, but also the translation of texts from one system to another. For example, translation from the adult system into the children's. That is why it is important to have a translation naturally and accurately. A translation can be considered as a natural translation if it sounds like not a translation work. While, an accuracy in the translation means that, the translator should be to re-communicate the meaning of the original message as precisely as a possible in the language into which he/she is translating.

Furthemore, it can be said that, translating is not an aesy thing to do, especially in translating literary works. Literary works is a kind of texts which is usually translated by many translators. Short story is a type of literary works. Translating literary work is more difficult than translating other types of text since literary works have specific values called the aesthetic and expressive values. So, the translator should have a special quality, especially in transferring message from SL to TL which is make a translation is acceptable or easy to be understood by the reader.

Here, the researcher choose the story entitled The Proud Lion because this story listed as "The Favourite Stories from Asia " which created by Leon Chomber. Also, the other reason why the researcher chooses this short story because it only has one page which consist of 257 words and this short story is often read by students, teachers, and other readers. This story tells us about the Lion who is very proud of himself, he though he does not need any help for others especially little animals like rat. Even tough the lion ever caught the rat but in fact it still went to rescue the lion in trouble. The story have moral values that is useful for students, at-least three moral lessons from story; a good act gets its return, even the strongest may need help, and everything counts in life, even the smallest.

According to recent research (Muapiah, 2010) in translating short story text was caused many problems. The problems were lack of English vocabulary and disability to translate it into Indonesia effectively, the students had limited English knowledge which became disability for them to make a good translation. Most of student were not able to replace or transfer message from source language to target language and some times the students did not see the whole of context, but they saw one by one the words that will translated into a sentence. This article will try to show how students can achieve the naturalness and accuracy in translating a text by analyzing their translation work.

\section{PURPOSE AND RESEARCH QUESTIONS}

The purpose of this study was to to find out the naturalness and the accuracy of students short story translation. In line with the perpose of the study, the following research question were posed. 
1. How natural is English short story translation into Indonesian written by the second year students of MTsN 1 Makassar?

2. How accurate is English short story translation into Indonesian written by the second year students of MTsN 1 Makassar?

\section{LITERATURE REVIEW}

\section{The Concept of Translation}

a. Definition of Translation

Translation is an attempt to restate ideas from one language to another. Translation implicates existence of two languages, namely the source (SL) and target language (TL). Source language is the language of the text translated and target language is the language text of the translation. For example, if we translate English text into Indonesian language, English will be source language and Indonesian is the target language.

Translation has been defined in many ways by different writers in the field, depending on how they view language and translation. There are some definitions as translation is the replacement of textual material in one language by equivalent textual material in another language (Nababan 2008:19). Translation consists of reproducing in the receptor language the closest Natural equivalent of the source language message, first in terms of meaning and secondly in terms of style. (Nida, 1969:12). Translation is a craft consists of attempt to replace a written message or statement in one language by the same message or statement in another language (Newmark, 1988:7)

\section{Naturalness in Translation}

The naturalness in target language should be achieved in order to make the readers of the translated version do not realize that they are reading a translation product. Nida and Taber (2005: 3) say that translating consists in reproducing in the receptor language the closets natural equivalence of a source language message, firstly in terms of meaning and secondly in terms of style. To be able to produce the closest natural equivalence, a translator has to master the message in the original text up to the details, then he has to restructure it.

From the explanation of naturalness in translation above, the researcher can conclude that translation should be natural in forms of meaning and structure (grammar). So, the translators should make the translation be equivalent and natural in the forms of meaning and structure (grammar). They should do it in order to make the readers of the translated version do not realize that they are reading a translation product. They can do it on many kinds of translation.

\section{Accuracy in Translation}

Accuracy in translation consists of studying the lexicon, grammatical structure, communication situation and cultural context of the source language text, analyzing it in order to determine its meaning and then reconstructing this same meaning using the lexicon and grammatical structure which are appropriate in the receptor language and its cultural 
context (Larson, 1998:3). Larson explained that the accuracy test can be done by five methods, i.e.:

a) compare the translation result with the source text at several points in the total project during the translation process,

b) after the comparison complete, do one more careful comparison,

c) when checking for equivalence of information context, make sure that the information is include - nothing omit, nothing add and nothing different,

d) after checking to be sure that all of the information is there, make another comparison of source language and target language text. Larson also said that maintaining the dynamics of the original source text means that the translation is presented in such a way that it will, hopefully, evoke the same response as the source text attempted to evoke.

According to the statements above, the study concludes that a translation can be said accurate if it does not deviate from the context or information on the source text. If the result of translation does not match with the meaning on target language and context, it can be said that the translation is not accurate. In addition, the most important thing of the result of translation is an original work that maintains the meaning and context from source language.

\section{RESEARCH METHOD}

\section{Subject of the Research}

The subjects of this research were the students at the second year of MTsN 1 Makassar in Academic years 2017/2018. The researcher used purposive sampling technique by taking one class from the twelve classes of the second year students of MTsN 1 Makassar. The researcher choose Class VIII-11.

\section{Instrument of the Research}

To collect the data the researcher applied two instruments to elicit students' naturalness and accuracy in translating short story. The first instrument is document by the translation test. The reason why the researcher used a test as instrument was that through translation the students create their translation work. So it would be easier for the researcher to analyze and classify the data. The students assigned to translate the story. And the second was interview to support the analytical process of the data.

\section{Procedure of Collecting Data}

The procedure of collecting data in this research were as follows:

1. Analyzing the Text

2. Try out to the students

3. Collecting Documents

4. Interviewing 
The researcher gave some questions to the participants in order to get additional data. These were two question given:

a. What are the problems that exist in translating the text?

b. How do students solve the problems?

\section{Findings and Discussion.}

\section{Analysis of Naturalness and Accuracy of student's work}

The result from naturalness and accuracy aspect from the students work gained score 7-8 with classification almost completely succesful from 30 students. And 10 students gained score score 5-6 with classification adequate.

a. Analysis of Naturalness

Example:

1) SL: One day, a rat walked past a lion sleeping

TL: Disuatu hari, seekor tikus berjalan melewati seekor singa yang sedang tidur. ( Datum s28)

2) SL: "Mr. Lion, King of the forest,"

TL: Pak singa, si raja hutan. (Datum s2)

3) SL: He caught it with his paw.

TL: ia menangkap dengan cengkramannya. ( Datum s6)

Almost succesful score is caused by there were several words which were not appropriate used by the students in translating short stories from English into Indonesian. Clssifying students scores based on Waddington translation assessment rubric in naturalness aspect is only large section read like a piece originally written in source language and the meaning between TL and SL was closest. There are number of common grammar, correct meaning, using appropriate idioms and words but there are some error structures. The example from the story entitled The Proud Lion was considered to fall into almost succesful score.

However, there were several mistakes made by the students. In the first example, the student did not use the appropriate word in translating the SL into the TL. The student translated the word one day into di suatu hari in the sentence One day, a rat walked past a lion sleeping. The mistake that the student use made the sentence sounded unnatural because using preposition $d i$ - is not commonly used by someone to tell an event that has happened before especially in the first sentence of the story. In this case, the student just should use suatu hari or pada suatu hari to translate the word one day. Therefore, the appropriate word that is used to translate one day is pada suatu hari. In the second exampl, the student use of courtesy tittle pak on the sentence "Pak singa, si raja hutan" in translating "Mr. Lion, King of the forest,". Eventhough it has same meaning in real context to show honorific or respect to each other but in the story or fables the suitable word that is always used to translate the word Mr. Lion is Tuan Singa. The third is the use word cengkramannya to translate his paw in the sentence he caught with his paw. The students 
did not use the appropriate word in translating the SL into the TL. Therefore, the translation between the TL was not equivalent with the SL. Student should translated his paw into cakarnya in order to make it not sounds strange.

Another result from naturalness aspect from students work gained score score 5-6 with classification adequate from 10 students.

Example

1) SL: "Mr. Lion," said the rat, "yesterday you were very proud.

TL: Tuan singa, mengatakan tikus itu, " kemarin anda sangat bangga. ( Datum s21)

2) SL: But since he was not feeling very hungry, he let the rat go.

TL: tapi sejak dia tidak merasa sangat lapar, dia membiarkan tikus itu pergi

( Datum s24)

3) SL: "What a tasty meal!" he said.

TL: Makanan yang lezat! Dia bilang ( Datum s30)

Adequate score might be caused by the ungrammatical structures on the TL and by the several words which were not appropriate to be used to translate the SL. Clssifying students scores based on Waddington translation assessment rubric in naturalness aspect is only certain parts read like a piece originally written in source language but others read like a translation product. The translation is make sense with minimum unnatural words. There are considerable number of common grammar, idioms or word for word. This category is a translation which has the correct meaning but there are some words which are not appropriate to be used and also there is ungrammatical structure that is done by the translator. The student should make the translation be equivalent and natural in the forms of meaning and structure (grammar). They should do it in order to make the readers of translated version do not realize that they are reading a translation product.

The first example, the student translate the sentence said the rat into mengatakan tikus itu. It is no need to add the prefix me- and suffix -an in the word mengatakan. The mistake that was made by the student made the sentence sounded unnatural. It is direct speech sentence, so the student should use kata tikus itu to translate the sentence said the rat. The direct and indirect speech in that story is a language feature with dominantly used. The second mistake is the student use word since in the sentence but since he was not feeling very hungry, he let the rat go into tapi sejak dia tidak merasa sangat lapar, dia membiarkan tikus itu pergi. The word since in the sentence is not relate with the time or perfect tense but it is a conjunction that used to express the reason. Therefore, the translation between the TL was not equivalent with the SL. The appropriate word that could be used to translate the word "since" is "karena. So, the sentence but since he was not feeling very hungry, he let the rat go should be translate into tapi karena dia tidak merasa sangat lapar, dia membiarkan tikus itu pergi. The third mistake that student use to translate the direct sentence "he said" into dia bilang. Student should translated he said into ckata dia in order to make it not sounds strange.

b. Analysis of Accuracy 
Example

1) SL: But since he was not feeling very hungry, he let the rat go.

TL: Tapi singa merasa tidak terlalu lapar, dia melepaskan tikus itu. ( Datum s1)

2) SL: I'm too small to make a good meal for you

TL: Aku kecil untuk sebuah daging yang bagus untuk mu ( Datum s5)

3) SL: "What a tasty meal!" he said.

TL: Makanan yang lezat! dia bilang. ( Datum s17)

Classifying students scores based on Waddington translation assesment rubris is almost completely transfer, the content of the source language is accurately conveyed to the target language, the translated can be clearly understood by the evaluator but there may be one or two insignificant inaccuracies that require a certain amount of revision to such professional standart and some rewriting and some change in word order are needed. The example from the story entitled The Proud Lion was considered to fall into almost succesfull score.

However, there were several mistakes made by the students. In the first example, the student did not complete the sentence into Indonesian. The student translate the sentence But since he was not feeling very hungry, he let the rat go into tapi singa merasa tidak terlalu lapar, dia melepaskan tikus itu. The student missed the word since to be translated. The student should make the translation be equivalent with the target language. The appropriate of whole sentence should be tapi karena singa merasa tidak terlalu lapar, dia melepaskan tikus itu. It also happens in the second example, the student missed the word too to be translated in the sentence I'm too small to make a good meal for you. The student should complete the sentence to make it equivalent in the source language. The appropriate sentence should be saya terlalu kecil untuk dijadikan santapan yang lezat bagimu. In the third sentence, the student did not use the appropriate word in translating the SL into the TL. The student translated the sentence what a tasty meal into makanan yang sangat lezat, whereas the sentence what a tasty meal is an exclamatory sentence means a sentence that expressing strong feelings or excitement by making an exclamation marks in the end of the sentence. The student should add the word sungguh or betapa to translate the sentence what a tasty meal. Therefore, the appropriate sentence that is used to translate what a tasty meal is sungguh makanan yang lezat!. Another result from accuracy aspect from the students work gained score score 5-6 with classification Adequate.

Example

1) SL: You thought I was small and useless. Today, I was able to save your life. I hope you will never forget that, although you are big and strong, even someone as small as I can help you.

TL: Kamu pikir saya kecil dan tak berguna. Hari ini saya bisa menyelamatkan hidupmu. Saya harap kamu tidak akan melupakan itu meskipun kamu besar dan kuat, bahkan seseorang sekecil yang bisa saya bantu. ( Datum s26)

2) SL: "Mr. Lion, King of the forest," cried that rat, "please have a pity on me.

TL: Tuan singa, Si Raja hutan, tanya si tikus, tolong kasihanilah saya. ( Datum s32) 
3) SL: "What a tasty meal!" he said.

TL: Sebuah daging yang enak!" dia bilang. ( Datum s33) ( Datum s26)

Classifying students scores baseed on Waddington translation assesment rubric is transfer of general idea but with a number lapses in accuracy; needs considerable revision to reach professional standart. of the source sentence is not accurately conveyed to the target sentence. There are some problems with the choice of lexical items and with the relationships between phrase, clause and sentence. In order to determine its meaning, the students have to reconstracting this same meaning using the lexicon and grammatical structure which are appropriate in the receptor language and its cultural context.

There were several mistakes that were made by the students which caused inacurate translation. The first mistake for example in the first the student did not use the appropriate word in translating the SL into the TL. The student translated the sentence even as small as I can help you into bahkan sekecil yang bisa saya bantu. The meaning of the sentence between the SL and the TL was actually different. In this case, the structure using as + adjective + as to make comparisons when the things we are comparing are equal in some way. So, the student should use bahkan sekecil saya bisa menolong mu to translate even as small as I can help you. In the example number 2-4 the student translated the sentences is not equivalent with the source language. The meaning of the sentence between the SL and the TL was different. In this case, the translator should use makanan to translate the word meal. The word makanan has the same meaning with the word meal. Therefore, the appropriate word that is used to translate meal is makanan.

According to the result of data analysis, the researcher concluded that the naturalness and accuracy of students translation was almost completely successful. This was proved by the result of students which classified as "almost completely successful" score. The majority they translated the text well, but a few students still had skill that were low. In order to be clear, the researcher would like to discuss the students score of translating children's stories. There were 30 students got $7 / 8$ that was classified almost completely successful and 10 student got $5 / 6$ were classified as adequate.

Most of students had a good translation, they could express the message in target language accurately and the readers could get the information that they expressed, but a few of students were still less in translating test, based on their interview, they had more problem such as less vocabulary, used word for word translation and they were still less in selecting the indicated meaning. They made wrong choice of words and their translation sound strange and unnatural for readers.

Some of students who did the translation were lack in choose the equivalent of word, so that the messege could be understood but words that used in target language were not equivalent with the source language. The students ability to construct sentence correctly and properly. The important to be known was in translating English to Indonesian. We may use our own words which had nearly meaning the test. So that our translation did not sound strange, acceptable and comprehensible. 


\section{CONCLUSION}

Based on the result of the data analysis and the findings in the previous chapter, the researcher would like to give conclusion related to the naturalness and accuracy of students in the second year of junior high school of MTsN 1 Makassar translation work of a text in their translation worksheet about children's story entitled The Proud Lion.

1. The naturalness of students translation of children's story entitled The Proud Lion was classified as almost completely successful but a few of student still had low ability in translating the story. They got score 5-6 which was classified as adequate. It was caused by wrong choice of words, therefore their translation sound strange and unnatural.

2. The accuracy of students translation of children's story entitled The Proud Lion was classified as almost completely successful but a few of student still had low ability in translating the story. They got score 5-6 which was classified as adequate. They had more problem such as less vocabulary, used word for word translation and they were still less in selecting the indicated meaning. The meaning of the sentence between the SL and the TL was different. Therefore,It made the sentence inacurate.

\section{SUGGESTIONS}

By considering the conclusion above, the researcher gives some suggestion;

1. Translation is one of skill that most important to be known by students to get information in one language, especially in English.

2. The teacher should always give materials that realate to the translation to increase the student's translation skill.

3. The teacher should give more exercise, guidance and motivation to the students to do translation especially in translating english paragraphs text in naturalness and accuracy side into Indonesian or Indonesian to English text.

\section{REFERENCES}

Baker, Mona (1992). In Other Word A Course Book on Translation. London: Routledge Barker. (1995). The social Work Dictionary; National Association of Social Workers.

Larson, Mildred L.1984. Meaning Based Translation America: University Press of America

Lathifah, U. (2016). Analyzing students' translation procedures in translating short story entitled 'The Story of an Hour'by Kate Chopin into Indonesian (a study at the 6th semester of ELT Department of Walisongo State Islamic University in the academic year of 2016/2017) (PhD Thesis). UIN Walisongo. 
Muapiah, Nur. (2010). The Ability of The Third Year Students of Madrasah Aliyah (MA) Madani Alauddin Pao-Pao Gowa TO Translate English Short Story Text.. PBI UIN Alauddin

Nababan, M. Rudolf. (1999). Aspek Teori Penerjemahan dan Pengalih bahasaan. Yogyakarta

Nababan, Rudolf (2008). Teori Penerjemahan Bahasa Inggris. Yogyakarta: Pustaka Belajar.

Newmark, P. (1988). A Textbook of Translation: Prentice Hall.

Newmark, Peter (1988). Textbook of Translation. New York: Prentice-Hall International Nida, E.A. and Charles. R Taber (1974). The Theory and Practice of Translation. Leiden: Shavit, Zohar (1986). Poetics of Children's Literature. University of Georgia Press. 